ISSN 2442-3041

Math Didactic: Jurnal Pendidikan Matematika

Vol. 1, No.1, Januari - April 2015

(c) STKIP PGRI Banjarmasin

\title{
MEMBENTUK KARAKTER PESERTA DIDIK MELALUI MODEL PEMBELAJARAN SEARCH, SOLVE, CREATE, AND SHARE ${ }^{6}$
}

\author{
Hasby Assidiqi \\ Program Studi Pendidikan Matematika IAIN Antasari Banjarmasin \\ E-mail: hasbymath19@gmail.com
}

\begin{abstract}
Matematika merupakan ilmu universal yang mendasari perkembangan sains dan teknologi, mempunyai peran penting dalam berbagai disiplin ilmu dan memajukan daya pikir manusia. Oleh karena itu, pembelajaran matematika harus dirancang dengan baik sedemikian sehingga dapat digunakan sebagai wahana dalam meningkatkan kemampuan akademis dan membentuk karakter positif peserta didik. Salah satu model pembelajaran yang dapat mengakomodasi ranah tersebut, yaitu model pembelajaran Search, Solve, Create, and Share (SSCS).
\end{abstract}

Kata kunci: karakter, model SSCS

Bangsa Indonesia saat ini disinyalir sedang mengalami keterpurukan dan keterbelakangan serta penurunan kualitas moral. Hal ini ditandai dengan munculnya degradasi moral yang tidak saja menimpa kepada pelajar dan mahasiswa, tetapi keadaan sudah mewabah dimasyarakat luas. Secara kasat mata degradasi moral itu tampak pada perilaku keseharian masyarakat, seperti tergesernya nilai sopan santun dan penyimpangan perilaku yang lain, seperti mabuk, sex bebas, narkoba, tawuran, kebut-kebutan, dan sebagainya. Lebih luas lagi degradasi moral itu, sudah mewabah secara kronis, seperti berbohong, mencuri, berjudi, aborsi bahkan pembunuhan. Permasalahan tersebut, terus berkembang dimasyarakat sepertinya menjadi tidak terkendali yang kemudian menjadi penyakit sosial semakin parah, seperti merabaknya paham individualistis, yakni lebih suka mementingkan diri sendiri dan kelompok daripada kerja sama dalam bermasyarakat, munculnya permasalahan bangsa yang sarat dengan korupsi, kolusi, dan nepotisme, dan maraknya kebohongan publik dari pemimpin bangsa (Salimin, 2011:3).

Di kalangan pelajar dan mahasiswa degradasi moral ini tidak kalah meprihatinkan. Kebiasaan "mencontek" pada saat ulangan atau ujian masih dilakukan. Keinginan lulus dengan cara mudah dan tanpa kerja keras pada saat ujian nasional menyebabkan mereka berusaha mencari jawaban dengan cara yang tidak beretika. Mereka mencari "bocoran jawaban" dari berbagai sumber yang tidak jelas. Apalagi jika

\footnotetext{
${ }^{6}$ Disampaikan pada Seminar Nasional Pendidikan Matematika STKIP PGRI Banjarmasin, 28 Januari 2015
} 
keinginan lulus dengan mudah bersifat institusional karena direkayasa atau dikondisikan oleh pimpinan sekolah dan guru secara sistemik. Perilaku tidak beretika juga ditunjukkan oleh mahasiswa. Plagiarisme atau penjiplakan karya ilmiah dikalangan mahasiswa juga masih bersifat massif. Bahkan ada yang dilakukan oleh mahasiswa program doktor. Fenomena lain yang mencoreng citra pelajar adalah maraknya "geng pelajar" dan "geng motor". Perilaku mereka bahkan seringkali menjurus pada tindakan kekerasan (bullying) yang meresahkan masyarakat dan bahkan tindakan kriminal seperti pemalakan, penganiayaan, bahkan pembunuhan (kemendiknas,2010:2)

Semua perilaku negatif tersebut di atas, jelas menunjukkan kerapuhan karakter yang cukup parah yang salah satunya disebabkan oleh lunturnya nilai-nilai karakter bangsa. Dalam konteks ini, karakter merupakan nilai-nilai perilaku manusia yang berhubungan dengan Tuhan Yang Maha Esa, diri sendiri, sesama manusia, lingkungan, dan kebangsaan yang terwujudnya dalam pikiran, sikap, perasaan, perkataan, dan perbuatan berdasarkan norma-norma agama, hukum, tata krama, budaya dan adat istiadat. Lunturnya nilai-nilai tersebut, hakikatnya merupakan bagian dari karakter individu. Individu yang memiliki karakter baik adalah individu yang bisa membuat keputusan dan siap mempertanggung jawabkan setiap akibat dari perbuatannya. Demikian sebaliknya, individu yang berkarakter jelek jauh dari perbuatan terpuji.

Upaya merespon kondisi tersebut di atas, nilai-nilai karakter perlu dikenalkan kembali kepada peserta didik melalui pendidikan, karena pendidikan memiliki peran penting dan sentral dalam pengembangan potensi manusia, termasuk potensi mental. Melalui pendidikan diharapkan terjadi tranformasi yang dapat menumbuhkembangkan karakter positif serta mengubah watak dari yang tidak baik menjadi baik. Ki Hajar Dewantara dengan tegas menyatakan bahwa "pendidikan" merupakan daya upaya untuk memajukan bertumbuhnya budi pekerti (kekuatan batin, karakter), pikiran (intellect), dan tubuh anak. Jadi jelaslah, pendidikan merupakan wahana utama untuk menumbuhkan karakter yang baik. Di sinilah pentingnya pendidikan karakter. (Kemendiknas, 2010:3-4)

Menurut Asosiasi Lembaga Pendidikan Tenaga Kependidikan Indonesia (ALPTKI), pendidikan karakter perlu dikembangkan sebagai berikut: 1) Karakter sebagai perekat kultural yang memuat nilai-nilai seperti kerja keras, kejujuran, disiplin, etika, estetika, komitmen, rasa kebangsaan dll, 2) Pendidikan karakter merupakan proses berkelanjutan, 3) pendidikan karakter sebagai landasan legal formal untuk tujuan pendidikan dalam ketiga ranah, yaitu ranah kognitif, ranah afektif, dan ranah psikomotorik, 4) Proses pembelajaran sebagai wahana pengembangan karakter dan IPTEKS, 5) Melibatkan beragam aspek pembangunan peserta didik, dan 6) Sekolah sebagai lingkungan pembudayaan peserta didik. (Ghozi dalam Utari Sumarmo, 2011:23)

Pembentukan karakter merupakan salah satu dari tujuan pendidikan nasional. Pasal 1 UU Sisdiknas No 20 tahun 2003 menyatakan bahwa di antara tujuan pendidikan nasional adalah mengembangkan potensi peserta didik untuk memiliki kecerdasan, kepribadian, dan akhlak mulia. Pesan dari UU sisdiknas tahun 2003 bertujuan agar pendidikan tidak hanya membentuk insan yang pintar, namun juga berkribadian. Dengan demikian nantinya akan lahir generasi muda berkarakter dan berilmu serta berkepribadian yang bernafaskan nilai-nilai luhur agama dan pancasila. Tujuan pendidikan nasional yang bersifat normatif ini harus dijabarkan, dieksplisitkan, dan diimplementasikan dalam praktik pembelajaran, termasuk pembelajaran matematika. 
Matematika merupakan ilmu universal yang mendasari perkembangan sains dan teknologi, mempunyai peran penting dalam berbagai disiplin ilmu dan memajukan daya pikir manusia. Oleh karena itu, pembelajaran matematika harus dirancang dengan baik sedemikian sehingga dapat digunakan sebagai wahana dalam membelajarkan karakter positif kepada peserta didik. Melalui pembelajaran matematika, secara eksplisit maupun implisit, dapat dibelajarkan kepada peserta didik berbagai karakter positif seperti kemampuan berpikir kritis, logis, cermat, analitis, sistematis, dan konsisten dalam bersikap, bahkan untuk mengembangkan nilai-nilai kemanusiaan (Mahmudi, 2011:75).

Salah satu model pembelajaran yang dapat mengakomodasi ranah kognitif peserta didik, tetapi juga dapat membentuk karakter peserta didik seperti tersebut di atas, yaitu Model pembelajaran Search, Solve, Create and Share (SSCS). Pembelajaran Matematika melalui Model SSCS ini terdiri dari empat fase, yaitu fase mendefinisikan masalah (search), fase merencanakan dan melaksanakan solusi (solve), fase menformulasikan hasil (create) dan fase mengkomunikasikan hasil (share).

\section{Pengertian Karakter dan Pendidikan Karakter}

Secara etimologi, kata karakter dapat dipahami dari sejumlah bahasa. "Character" (Latin) berarti instrument of narking, "charessein" (prancis) berarti to engrave (mengukir), "watek (jawa) berarti ciri wanci, "watak" (Indonesia) berarti sifat pembawaan yang mempengaruhi tingkah laku; budi pekerti; tabiat; perangai (Koesoema, 2007:163). Jadi istilah berkarakter artinya memiliki karakter, memiliki kepribadian, berperilaku, bersifat, bertabiat, dan berwatak. Individu yang berkarakter baik dan unggul adalah seseorang yang berusaha melakukan hal-hal yang terbaik terhadap hubungannya dengan Tuhan Yang Maha Esa, diri sendiri, sesama manusia, lingkungan, dan kebangsaan yang terwujud dalam pikiran, sikap, perasaan, perkataan, dan perbuatan berdasarkan normanorma agama, hukum, tata krama, budaya dan adat istiadat. Orang yang perilakunnya sesuai dengan norma-norma tersebut disebut berkarakter mulia (Gunawan, 2014:5).

Secara terminologi, menurut Alwisol (2006:8) mengartikan karakter sebagai gambaran tingkah laku yang menonjolkan nilai benar-salah, baik-buruk, baik secara eksplisit maupun impilisit. Terkait dengan ini, Wynne (1991:45) mengatakan kata karakter berasal dari bahasa Yunani yang berarti "to mark" (menandai) dan menfokuskan pada bagaimana mengaplikasikan nilai kebaikan dalam bentuk tindakan atau tingkah laku. Oleh sebab itu seseorang yang berperilaku tidak jujur, kejam, atau rakus dikatakan sebagai orang yang berkarakter jelek, sementara orang yang berperilaku jujur, suka menolong dikatakan sebagai orang yang berkarakter mulia. Jadi istilah karakter erat kaitannya dengan personality (kepribadian) seseorang, di mana seseorang bisa disebut orang yang berkarakter (a person of character) jika tingkah lakunya sesuai dengan kaidah moral yang berlaku.

Karakter mengacu pada serangkaian sikap (attitudes) dan perilaku (behaviors). Karakter meliputi sikap seperti keinginan untuk melakukan hal yang terbaik, kapasitas intelektual seperti berfikir kritis dan alasan moral, perilaku seperti jujur dan bertanggung jawab, mempertahankan prinsip-prinsip moral dalam situasi penuh keadilan, kecakapan interpersonal dan emosional yang memungkinkan seseorang berinteraksi secara efektif dalam berbagai keadaan, dan komitmen untuk berkontribusi dengan komunitas dan masyarakatnya. Karakteristik adalah realisasi perkembangan positif sebagai individu (intelektual, sosial, emosional, dan etika). Individu yang berkarakter baik adalah 
seseorang yang berusaha melakukan hal yang terbaik (Musfiroh, 2008:25).

Ratna megawangi (dalam Mariani, 2011:153) sebagai pencetus pendidikan karakter di Indonesia telah menyusun karakter mulia yang selayaknya diajarkan kepada anak, yang kemudian disebut sebagai 9 (Sembilan) pilar yaitu: (1) cinta Tuhan dan kebenaran (love Allah, trust, reverence loyalty), (2) Tanggung jawab, kedisiplinan dan kemandirian (responsibility, excellence, self reliance, discipline, orderliness), (3) Amanah (trustworthiness, reliability, honesty), (4) Hormat dan Santun (respect, courtesy, obedience), (5) Kasih sayang, kepedulian, dan kerjasama (love compassion, caring, empathy, geneoursity, moderation, cooperation), (6) Percaya diri, kreatif, dan pantang menyerah (confidence, assertiveness, creativity, resourcefulness, courage, determination and enthusiasm), (7) Keadilan dan kepemimpinan (justice, fairness, mercy, leadership), (8) Baik dan rendah hati (kindness, friendliness, humility, modesty), (9) Toleransi dan cinta damai (tolerance, flexibility, peacefulness, unity).

Ary Ginanjar Agustian (2007:13) dengan teori ESQ menyodorkan pemikiran bahwa setiap karakter positif sesungguhnya akan merujuk kepada sifat-sifat mulia Allah, yaitu al-Asma al Husna. Sifat-sifat dan namanama mulia Tuhan inilah sumber inspirasi setiap karakter positif yang dirumuskan oleh siapapun. Dari sekian banyak karakter yang bisa diteladani dari nama-nama Allah itu, Ary merangkumnya dalam 7 karakter dasar, yaitu jujur, tanggung jawab, disiplin, visioner, adil, peduli, dan kerjasama.

Badan penelitian dan pengembangan, Pusat Kurikulum Kementerian Pendidikan Nasional (2011:9-10) telah merumuskan nilainilai pendidikan karakter yang bersumber dari Agama, pancasila, budaya dan tujuan pendidikan nasional sebagai berikut:
1. Religius, yakni sikap dan perilaku yang patuh dalam melaksanakan ajaran agama yang dianutnya, toleran terhadap pelaksanaan ibadah agama lain, dan hidu rukun dengan pemeluk agama lain.

2. Jujur, yakni perilaku yang didasarkan pada upaya menjadikan dirinya sebagai orang yang selalu dapat dipercaya dalam perkataan, tindakan, dan pekerjaan, baik terhadap diri dan pihak lain.

3. Toleransi, yakni sikap dan tindakan yang menghargai perbedaan agama, suku, etnis, pendapat, sikap, dan tindakan orang lain yang berbeda dari dirinya.

4. Disiplin, yakni tindakan yang menunjukkan perilaku tertib dan patuh pada berbagai ketentuan dan peraturan.

5. Kerja keras, yakni perilaku yang menunjukkan upaya sungguh-sungguh dalam mengatasi berbagai hambatan belajar dan tugas serta menyelesaikan tugas dengan sebaik-baiknya.

6. Kreatif, yakni berfikir dan melakukan sesuatu untuk menghasilkan cara atau hasil baru dari sesuatu yang telah dimiliki.

7. Mandiri, yakni sikap dan perilaku yang tidak mudah tergantung pada orang lain dalam menyelesaikan tugas-tugas.

8. Demokratis, yakni cara berfikir, bersikap dan bertindak yang menilai sama hak dan kewajiban dirinya dengan orang lain.

9. Rasa Ingin Tahu, yakni sikap dan tindakan yang selalu berupaya untuk mengetahui lebih mendalam dan meluas dari sesuatu yang dipelajarinya, dilihat, dan didengar.

10. Semangat Kebangsaan, yakni cara berfikir, bertindak, dan berwawasan yang menempatkan kepentingan bangsa dan Negara di atas kepentingan diri dan kelompoknya.

11. Cinta Tanah Air, yakni cara berfikir, bersikap dan berbuat yang menunjukkan kesetiaan, kepedulian, dan penghargaan yang tinggi terhadap bahasa, lingkungan fisik, sosial, budaya, ekonomi, dan politik bangsanya. 
12. Menghargai prestasi, yakni sikap dan tindakan yang mendorong dirinya untuk menghasilkan sesuatu yang berguna bagi masyarakat, dan mengakui, serta menghormati keberhasilan orang lain.

13. Bersahabat/komunikatif, yakni tindakan yang memperlihatkan rasa senang berbicara, bergaul, dan bekerjasama dengan orang lain.

14. Cinta damai, yakni sikap, perkataan, dan tindakan yang menyebabkan orang lain merasa senang dan aman atas kehadirannya.

15. Gemar membaca, yakni kebiasaaan menyediakan waktu untuk membaca berbagai bacaan yang memberikan kebaikan bagi dirinya.

16. Peduli lingkungan, yakni sikap dan tindakan yang selalu berupaya mencegah kerusakan pada lingkungan alam disekitarnya, dan mengembangkan upayaupaya untuk memperbaiki kerusakan alam yang sedang terjadi.

17. Peduli sosial, yakni sikap dan tindakan yang selalu ingin memberi bantuan pada orang lain dan masyarakat yang membutuhkan.

18. Tanggung Jawab, yakni sikap dan perilaku seseorang melaksanakan tugas dan kewajibannya, yang seharusnya dia lakukan, terhadap diri sendiri, masyarakat, lingkungan (alam, sosial dan budaya), Negara dan Tuhan Yang Maha Esa.

Dari uraian tersebut di atas, dapat disimpulkan bahwa karakter merupakan perilaku manusia yang berhubungan dengan Tuhan Yang Maha Esa, diri sendiri, sesama manusia, lingkungan, dan kebangsaan yang terwujud dalam pikiran, sikap, perasaan, perkataan, dan perbuatan berdasarkan normanorma agama, hukum, tata krama, budaya dan adat istiadat.

Pendidikan karakter adalah pendidikan untuk membentuk kepribadian seseorang melalui pendidikan budi pekerti yang hasilnya terlihat dalam tindakan nyata seseorang, yaitu tingkah laku yang baik, jujur dan bertanggung jawab, menghormati hak orang lain, kerja keras dan sebagainnya. Aristoteles berpendapat bahwa karakter itu erat kaitannya dengan kebiasaan yang dimanifestasikan dalam tingkah laku (Gunawan, 2014:23). Lebih lanjut dijelaskan pendidikan karakter adalah sesuatu yang dilakukan oleh guru/pendidik yang mampu mempengaruhi preserta didik. pendidik membantu membentuk watak peserta didik. Hal ini mencakup keteladanan bagaimana perilaku pendidik, cara pendidik berbicara atau menyampaikan materi, bagaimana pendidik bertoleransi dan berbagai hal terkait lainnya.

Berdasarkan grand design yang dikembangkan Kemendiknas, secara psikologis dan sosialkultural pembentukan karakter dalam diri peserta didik merupakan fungsi dari seluruh potensi individu manusia (kognitif, afektif, dan psikomotorik) dalam konteks sosial kultural (dalam keluarga, sekolah dan masyarakat) dan berlangsung sepanjang hayat. Konfigurasi karakter dalam konteks totalitas proses psikologis dan sosialkultural tersebut dapat dikelompokan dalam: (1) Olah hati (spiritual and emotional development), (2) Olah pikir (intellectual development), (3) olah raga dan kinestetik (physical and kinesthetic development), dan (4) olah rasa dan karsa (affective and creativity development). Keempat hal ini tidak dapat dipisahkan satu sama lainnya, bahkan saling melengkapi.

Pendidikan karakter yang baik harus melibatkan bukan saja aspek "pengetahuan yang baik (moral knowing), akan tetapi juga "merasakan dengan baik (moral feeling) dan perilaku yang baik (moral action). Pendidikan karakter menekankan pada habit atau kebiasaan yang terus menerus dipraktikan dan dilakukan. 
Berdasarkan uraian di atas, dapat ditegaskan bahwa pendidikan karakter merupakan upaya-upaya yang dirancang dan dilaksanakan secara sistematis untuk menanamkan nilai-nilai perilaku peserta didik yang berhubungan dengan Tuhan Yang Maha Esa, diri sendiri, sesama manusia, lingkungan dan kebangsaan yang terwujud dalam pikiran, sikap, perasaan, perkataan, dan perbuatan berdasarkan norma-norma agama, hukum, tata krama, budaya dan adat istiadat. meliputi kemampuan memahami masalah, merancang model matematika, menyelesaikan model dan menafsirkan solusi yang diperoleh, (4) Mengkomunikasikan gagasan dengan symbol, tabel, diagram, atau media lain untuk memperjelas keadaan atau masalah, (5) Memiliki sikap menghargai kegunaan matematika dalam kehidupan, yaitu memiliki rasa ingin tahu, perhatian, dan minat dalam mempelajari matematika, serta sikap ulet dan percaya diri dalam pemecahan masalah.

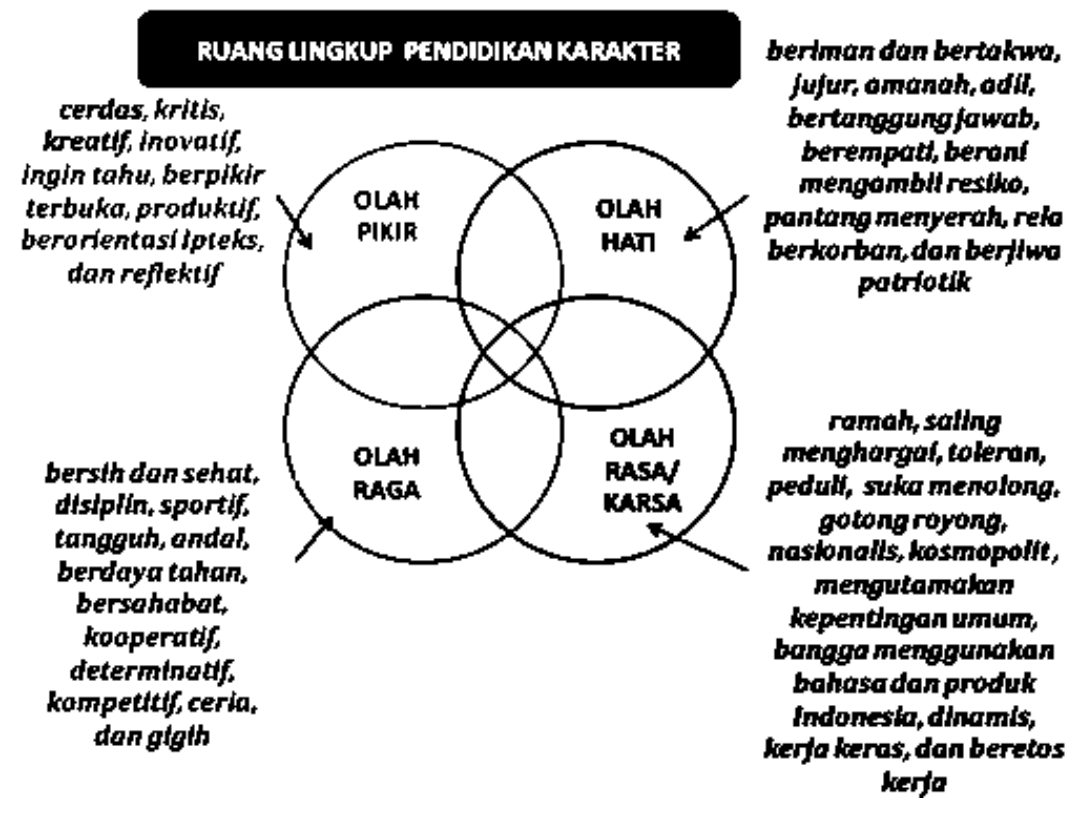

Koherensi karakter dalam konteks totalitas proses psikososial (Sumber: Desain Induk Pendidikan Karakter Kemendiknas, 2011:9)

\section{Hakikat Pembelajaran Matematika Sekolah}

Badan Standar Nasional Pendidikan tahun 2006 menyatakan bahwa pembelajaran matematika sekolah bertujuan untuk: (1) memahami konsep matematika, menjelaskan keterkaitan antar konsep dan mengaplikasikan konsep dan algoritma secara luwes, akurat, efisien, dan tepat dalam pemecahan masalah, (2) Menggunakan penalaran pada pola dan sifat, melakukan manipulasi matematika dalam membuat generalisasi, menyusun bukti, atau menjelaskan gagasan dan pernyataan matematika, (3) Memecahkan masalah yang
Dari penjelasan di atas terlihat bahwa pembelajaran matematika tidak hanya bertujuan untuk meningkatkan ranah kognitif peserta didik (butir 1 sampai dengan butir 4) tetapi juga kemampuan dalam ranah afektif (butir 5). Dalam pembelajaran matematika, pembinaan komponen ranah afektif akan membentuk disposisi matematik, yaitu: keinginan, kesadaran, dedikasi dan kecenderungan yang kuat pada diri peserta didik untuk berpikir dan berbuat secara matematik dengan cara positif dan didasari iman, takwa, dan akhlak mulia. (Utari Sumarmo, 2011:23). Pengertian disposisi matematik seperti di atas pada dasarnya sejalan dengan makna yang terkandung dalam 
pendidikan karakter. Dengan demikian pengembangan karakter seperti kemampuan berfikir dan disposisi matematik pada dasarnya dapat ditumbuhkan pada peserta didik secara bersama-sama.

\section{Polking dalam Utari Sumarmo} (2011:23) mengemukakan bahwa disposisi matematik meliputi sikap atau sifat: 1) rasa percaya diri dalam menerapkan matematika, memecahkan masalah, memberi alasan dan mengkomunikasikan gagasan, 2) lentur dalam menyelidiki gagasan matematik dan berusaha mencari beragam cara memecahkan masalah, 3) tekun mengerjakan tugas matematik, 4) minat, rasa ingin tahu dalam melakukan tugas matematik, 5) cenderung memonitor dan menilai penalaran sendiri, 6) mengaplikasikan matematika dalam bidang studi lain dan kehidupan sehari-hari, 7) apresiasi terhadap peran matematika dalam kultur dan nilai, matematika sebagai alat, dan sebagai bahasa.

Hampir serupa dengan pendapat Polking, NCTM dalam Utari Sumarmo (2011:23) mengemukakan bahwa disposisi matematik menunjukkan: rasa percaya diri, ekspektasi dan metakognisi, gairah dan perhatian serius dalam belajar matematika, kegigihan dalam menghadapi dan menyelesaikan masalah, rasa ingin tahu yang tinggi, serta kemampuan berbagi pendapat dengan orang lain. Pengetian disposisi matematik tersebut pada dasarnya sejalan dengan makna yang terkandung dalam pendidikan karakter. Oleh karena itu, pembelajaran matematika perlu mengutamakan pengembangan nilai-nilai dalam pendidikan karakter, kemampuan berfikir dan disposisi matematik yang terintegrasi dan dilaksanakan secara bersamaan. Pengutamaan tersebut semakin penting manakala dihubungkan dengan upaya menyiapkan lulusan yang kelak diharapkan memenuhi tuntutan kemajuan IPTEKS dan suasana bersaing yang semakin ketat, serta menjaga keutuhan Negara Kesatuan Republik Indonesia yang kita cintai. Oleh karena itu, diperlukan suatu pembelajaran matematika yang dapat mengembangkan karater peserta didik tersebut di atas. Salah satu model pembelajaran yang dapat dilakukan adalah dengan Model Search, Solve, Create, and Share (SSCS).

\section{Pembentukan Karakter Melalui Model Pembelajaran SSCS}

Model Pembelajaran SSCS adalah model yang mengajarkan suatu proses pemecahan masalah dan mengembangkan keterampilan pemecahan masalah (Pizzini $d k k$, 1988:23). Model ini pertama kali dikembangkan oleh Pizzini pada tahun 1988 pada mata pelajaran sains (IPA). Selanjutnya Pizzini, Abel dan Shepardson (1988) serta Pizzini dan Shepardson (1990) dalam menyempurnakan model ini dan mengatakan bahwa model ini tidak hanya berlaku untuk pendidikan sains saja, tetapi juga cocok untuk pendidikan Matematika. (Irwan, 2011:4).

Model SSCS ini didasari oleh teori kognitif dan kontruktivisme yang mengasumsikan bahwa anak memiliki rasa ingin tahu bawaan dan secara terus menerus berusaha memahami dunia sekitarnya dan menganggap bahwa kelas merupakan cermin masyarakat yang lebih besar dan berfungsi sebagai laboratorium untuk belajar memecahkan masalah kehidupan nyata (Rizki dalam Parwati, 2011:281). Asumsi lain adalah perkembangan intelektual akan terjadi pada saat individu berhadapan dengan pengalaman baru dan menantang serta ketika mereka berusaha untuk memecahkan masalah yang dimunculkan oleh pengalaman ini (Krulik $d k k$ dalam Parwati, 2011:281).

Model pembelajaran SSCS merupakan model pembelajaran yang terdiri atas empat fase, yaitu fase mengidentifikasi masalah (search), fase mendesain solusi (Solve), fase memformulasikan hasil (create) dan mengkomunikasikan hasil (share) (Pizzini dan Shepardson, 1992:5). Menurut 
Pizzini dkk sebagaimana dikutip oleh Chin (1997:10) menjelaskan secara rinci aktivitas yang dilakukan peserta didik pada keempat fase pada saat pembelajaran diantaranya dapat dilihat pada Tabel 1 berikut.
Pizzini dalam (Mardiah Hayati, 2006:14; Rahmi, 2011:3-4) menyatakan bahwa implementasi dari pembelajaran model SSCS ini adalah sebagai berikut:

1. Fase search. Pada fase ini, strategi yang

Tabel 1. Aktivitas peserta didik dalam pembelajaran SSCS

\begin{tabular}{|l|l|}
\hline \multicolumn{1}{|c|}{ Fase } & \multicolumn{1}{c|}{ Aktivitas yang dilakukan } \\
\hline Search & 1. Memahami soal atau kondisi yang diberikan kepada peserta didik yang berupa apa \\
& $\begin{array}{l}\text { 2. Mang diketahui, apa yang ditanyakan. } \\
\text { 3. Melakukan observasi dan investigasi terhadap kondisi tersebut. }\end{array}$ \\
\hline Solve & $\begin{array}{l}\text { 1. Menghasilkan dan melaksanakan rencana untuk mencari solusi. } \\
\text { 2. Mengembangkan keterampilan berfikir kritis sepeti kemampuan untuk memilih apa } \\
\text { yang harus dilakukan, bagaimana melakukan yang terbaik, data apa yang penting, } \\
\text { pengukuran harus akurat, bagaimana dan mengapa setiap langkah diperlukan dalam } \\
\text { proses mereka. }\end{array}$ \\
& $\begin{array}{l}\text { 3. Memilih metode untuk memecahkan masalah. } \\
\text { 4. Mengumpulkan data dan menganalisis. }\end{array}$ \\
\hline Create & $\begin{array}{l}\text { 1. Menciptakan produk yang berupa solusi masalah berdasarkan dugaan yang telah } \\
\text { dipilih pada fase sebelumnya. }\end{array}$ \\
& $\begin{array}{l}\text { 2. Menggambarkan hasil dan kesimpulan mereka sekreatif mungkin dan jika perlu } \\
\text { peserta didik dapat menggunakan grafik, poster, atau model. }\end{array}$ \\
\hline Share & $\begin{array}{l}\text { 1. Berkomunikasi dengan pendidik, teman sekelompok serta kelompok lain atas solusi } \\
\text { masalah. Peserta didik dapat menggunakan media rekaman, video, poster, dan laporan. } \\
\text { 2. Mengartikulasikan pemikiran mereka, menerima umpan balik, dan mengevaluasi } \\
\text { solusi. }\end{array}$ \\
\hline
\end{tabular}

Aktivitas pendidik dalam model pembelajaran SSCS adalah menfasilitasi pengalaman untuk menambahkan pengetahuan peserta didik (Pizzini sebagaimana dikutip oleh Ramson, 2010:8). Aktivitas pendidik lebih lengkap pada tiap fase disajikan dalam Tabel 2 berikut. dilakukan pendidik untuk mengadakan dan membimbing peserta didik pada fase penyelidikan adalah:

a. Stimulasi:

1) Pendidik mengingatkan konsep materi yang lalu yang berkaitan atau pengalaman peserta didik

Tabel 2. Aktivitas pendidik dalam pembelajaran SSCS

\begin{tabular}{|l|l|}
\hline \multicolumn{1}{|c|}{ Fase } & \multicolumn{1}{c|}{ Aktivitas yang dilakukan } \\
\hline Search & $\begin{array}{l}\text { 1. Menciptakan situasi yang dapat mempermudah munculnya pertanyaan. } \\
\text { 2. Menciptakan dan mengarahkan kegiatan. }\end{array}$ \\
& 3. Membantu dalam pengelompokan dan penjelasan permasalahan yang muncul. \\
\hline Solve & $\begin{array}{l}\text { 1. Menciptakan situasi yang menantang bagi peserta didik untuk berpikir. } \\
\text { 2. Membantu peserta didik mengaitkan pengalaman yang sedang dikembangkan dengan } \\
\text { ide, pendapat, atau gagasan peserta didik tersebut. }\end{array}$ \\
& 3. Menfasilitasi peserta didik dalam memperoleh informasi dan data. \\
\hline Create & $\begin{array}{l}\text { 1. Mendiskusikan kemungkinan penetapan audien dan audiensi. } \\
\text { 2. Menyediakan ketentuan dalam analisis data dan teknik penayangannya. } \\
\text { 3. Menyediakan ketentuan dalam menyiapkan presentasi. }\end{array}$ \\
\hline Share & $\begin{array}{l}\text { 1. Menciptakan terjadinya interaksi antara kelompok/diskusi kelas. } \\
\text { 2. Membantu mengembangkan metode atau cara-cara dalam mengevaluasi hasil } \\
\text { penemuan studi selama presentasi, baik secara lisan maupun tulisan. }\end{array}$ \\
\hline
\end{tabular}


dalam kehidupan sehari-hari terkait materi pelajaran.

2) Pendidik dapat mengajukan pertanyaan-pertanyaan yang bersifat konvergen untuk menjadi pengetahuan awal peserta didik terhadap pembelajaran saat itu.

b. Curah pendapat dan rangkaian konsep: Salah satu kegiatan yang akan dilakukan pada fase search ini adalah kegiatan curah pendapat yang dilakukan oleh anggota kelompok dalam menyelesaikan masalah dan membuat jaringan/rangkaian konsep yang berkaitan dengan permasalahan yang dimunculkan. Rangkaian konsep ini memuat informasi-informasi yang menyangkut dengan masalah yang akan dipecahkan. Pada bagian ini akan dilaksanakan hal-hal sebagai berikut:

1) Peserta didik dibagi menjadi beberapa kelompok, setiap kelompok membuat rangkaian konsep yang berkaitan dengan masalah serta berdiskusi untuk merumuskan masalah dari permasalahan yang diberikan.

2) Beberapa kelompok diminta untuk menyampaikan rangkaian konsep yang mereka hasilkan ke depan kelas melalui diskusi kelas. Pendidik memberi kesempatan kepada peserta didik untuk menggali ide dan kritiknya terhadap kelompok lain. Diskusi ini dipimpin oleh pendidik dengan megarahkan peserta didik tersebut untuk menghasilkan rangkaian konsep kelas tersebut.

2. Fase Solve: Pada fase ini, Peserta didik bekerja dalam kelompok untuk merancang atau menyusun langkah-langkah penyelesaian masalah dari permasalahanpermasalahan yang telah dirumuskan bersama. Hal-hal yang diperhatikan pada fase ini adalah:

a. Penyediaan media (misal:chart, alat peraga) dilakukan sebagai upaya meletakan ide-ide dasar dan diharapkan mampu membantu peserta didik dalam menyelesaikan masalah.

b. Pengumpulan data.

c. Peserta didik bekerja berdasarkan panduan kegiatan yang dijelaskan dalam media pembelajaran seperti: Modul, LKS, Hand out dan sebagainya. Setiap peserta didik melakukan pengamatan dan mengidentifikasi hal-hal yang didapat pada proses search (penyelidikan). Panduan media pembelajaran diharapkan dapat mengarahkan peserta didik untuk mengumpulkan data.

d. Pendidik memberikan bimbingan kepada kelompok yang memerlukan bantuan dan mengecek pekerjaan yang dilaksanakan oleh peserta didik di setiap kelompoknya.

e. Peserta didik merumuskan kesimpulan berdasarkan pengamatan.

3. Fase Create: Pada tahap ini, peserta didik mampu menghasilkan jawaban permasalahan dan pendidik mendorong peserta didik untuk menggambarkan mengapa peserta didik menyimpulkan hal tersebut. Berdasarkan tanggapan peserta didik di kelas, akan dievaluasi apakah peserta didik memperoleh informasi yang benar (valid) atau tidak tentang konsep yang dipelajari. Pendidik meminta peserta didik untuk mempertimbangkan kemungkinan jawaban lain.

4. Fase Share: Pada urutan dalam penyelesaian masalah, beberapa kelompok memperlihatkan hasil pekerjaan mereka di depan kelas, kelompok lain diminta untuk memberikan umpan balik dengan berdasar pada hasil pekerjaan mereka, hal ini 
dilakukan untuk menentukan solusi yang paling tepat. Pada akhir fase ini, pendidik bersama-sama peserta didik membuat suatu kesimpulan.

Berdasarkan karakteristik dari model SSCS tersebut di atas dapat diidentifikasi sebagai berikut: (1) Peserta didik secara aktif terlibat dalam proses pembelajaran, baik dalam tugas-tugas mandiri maupun kelompok. Hal ini akan membentuk sikap rasa ingin tahu, kerja keras, dan mandiri peserta didik dalam belajar. Selain itu melalui model SSCS ini, peserta didik dihadapkan pada masalah terbuka yang dapat dijawab dengan banyak cara ataupun dengan banyak jawab benar sehingga mengundang potensi intelektual dan pengalaman peserta didik dalam proses menemukan sesuatu yang baru. Hal ini tentunya akan melatih peserta didik untuk memiliki berfikir kritis, kreatif, logis, dan sistematis serta percaya diri. (2) Peserta didik belajar dari teman kerja melalui kerja kelompok, diskusi, saling mengoreksi. Hal ini tentunya menfasilitasi terbentuknya sikap karakter seperti toleransi, peduli sosial, demokratis, menghargai, bersahabat/komunikatif. (3) Perilaku peserta didik dibangun atas kesadaran diri. Hal ini tentu akan menfasilitasi terbentuknya karakter rasa ingin tahu. (4) Peserta didik mendapatkan pengalaman dalam menyelesaikan masalah secara runtut dan sistematis. Hal ini menfasilitasi peserta didik, agar kebiasaan cara berpikir ini dapat terealisasi di kegiatan matematika lainnya dan umumnya dapat terlaksana dikehidupan sehari-hari.

Dengan demikian pembelajaran dengan model SSCS ini diharapkan dapat membantu peserta didik belajar secara bermakna yang tidak hanya tujuan kognitif dicapai, tetapi secara implisit juga dapat membentuk karakter peserta didik diantaranya: sikap ingin tahu, mandiri, kerja keras, logis, kritis, bertanggung jawab, percaya diri, toleransi, peduli, taat aturan (disiplin), demokratis dan komunikatif dan karakter positif lainnya.

\section{Kesimpulan}

Model Pembelajaran SSCS adalah model yang mengajarkan suatu proses pemecahan masalah dan mengembangkan keterampilan pemecahan masalah. Model ini terdiri dari empat fase, yaitu fase mengidentifikasi masalah (search), fase mendesain solusi (Solve), fase memformulasikan hasil (create) dan mengkomunikasikan hasil (share). Pembelajaran matematika yang memuat komponen-komponen tersebut tidak hanya tujuan kognitif dicapai, tetapi tujuan untuk membentuk karakter peserta didik diharapkan dapat dicapai seperti: sikap ingin tahu, mandiri, kerja keras, logis, kritis, bertanggung jawab, percaya diri, toleransi, peduli, taat aturan (disiplin), demokratis dan komunikatif dan karakter positif lainnya.

\section{Daftar Pustaka}

Alwisol, 2006. Psikologi Kepribadian. Malang:UMM.

Ary Ginanjar Agustian, 2007. Rahasia Sukses Membangun Kecerdasan Emosi dan Spritual. Jakarta:Arga.

Badan Standar Nasional Pendidikan, 2006. Panduan Kurikulum Tingkat Satuan Pendidikan (KTSP). Jakarta: BNSP.

Chin, Christine, 1997. Promoting higher cognitive learning in science through a problem solving approach. REACT, 1997(1),7-11: National Institue of Education (Singapore)

Gunawan. H, 2014. Pendidikan Karakter (konsep dan implementasi). Bandung: Alfabeta Bandung.

Irwan, 2011. Pengaruh Pendekatan Problem Posing Model Search, Solve, Create And Share (SSCS) Dalam Upaya Meningkatkan Kemampuan Penalaran Matematis Mahasiswa Matematika. 
Jurnal Penelitian Pendidikan. vol.12. No.1, April 2011.

Kemendiknas, 2010. Kerangka Acuan Pendidikan Karakter. Direktorat Ketenagaan Direktorat Jenderal Pendidikan Kementerian Pendidikan Nasional. Jakarta.

Kemendiknas, 2011. Panduan Pelaksanaan Pendidikan Karakter. Badan Penelitian dan Pengembangan Pusat Perbukuan Kementerian Pendidikan Nasional. Jakarta.

Koesoema. A.D, 2007. Pendidikan Karakter (Strategi mendidik anak di zaman global). Jakarta:Grasindo

Mahmudi. A, 2011. Mengembangkan Karakter Siswa Melalui Pembelajaran Matematika. Prosiding Seminar Nasional Penelitian dan Pendidikan dan Penerapan MIPA. Fakultas MIPA. UNY.

Mariani, 2011. Pendidikan Karakter Di Indonesia Dalam Perspektif Pendidikan Islam. Jurnal Tarbiyah vol.1. No.2, JuliDesember 2011. ISSN.2088-6691.

Musfiroh. T, 2008. Tinjauan berbagai aspek character building: Pengembangan karakter anak melalui pendidikan karakter. Yogyakarta: Tiara Wacana Yogyakarta.

Parwati. N.N, 2011. Model Pembelajaran Pemecahan Masalah Berorientasi Pengembangan Pendidikan Karakter “ Kajian Teoritis Dalam Pembelajaran Matematika”. Jurnal Undiksha. vol.11. No.1, Tahun 2011.

Pizzini, Edward L.,Abel, Sandra K, dan Shepardson, Daniel P, 1988. Rethingking Thingking in The Science Clasroom. The Science Teacher, Desember.

Rahmi, 2011. Metode Pemecahan Masalah Model SSCS (Search, Solve, Create And Share) Dalam Pembelajaran Matematika.. Percikan. Vol. 120 Edisi Januari 2011. ISSN 0854-8986

Ramson, 2010. Model Pembelajaran Search, Solve, Create, and Share (SSCS) Untuk
Meningkatkan Pemahaman Konsep dan Keterampilan Berfikir Kritis Siswa SMP Pada Topik Cahaya. Tesis. Bandung:FMIPA UPI.

Salimin, Saridi, 2011. Membentuk Karakter yang Cerdas. Tulungagung: Cahaya Abadi.

Sumarmo. U, 2011. Pembelajaran Matematika Berbasis Pendidikan Karakter. Prosiding Seminar Nasional Pendidikan Matematika. Volume 1, ISBN 978-60219541-0-2. STKIP Siliwangi Bandung.

Wynne, E.A, 1991. Character and academics in the elementary school. In. J.S. Benigna (ed). Moral character, and civic education in the elementary school. Newyork: Teacher College Press. 